\title{
Ballast-Mounted PV Arrays: Phase 2 Phase 2 Final Report
}

\author{
Ascension Technology \\ A Division of Applied Power Corporation \\ PO Box 6314 \\ Lincoln, MA 01773 USA \\ Edward C. Kern, Jr. \\ Vice President \\ +17816846101
}




\section{DISCLAIMER}

This report was prepared as an account of work sponsored by an agency of the United States Government. Neither the United States Government nor any agency thereof, nor any of their employees, make any warranty, express or implied, or assumes any legal liability or responsibility for the accuracy, completeness, or usefulness of any information, apparatus, product, or process disclosed, or represents that its use would not infringe privately owned rights. Reference herein to any specific commercial product, process, or service by trade name, trademark, manufacturer, or otherwise does not necessarily constitute or imply its endorsement, recommendation, or favoring by the United States Government or any agency thereof. The views and opinions of authors expressed herein do not necessarily state or reflect those of the United States Government or any agency thereof. 


\section{DISCLAIMER}

\section{Portions of this document may be illegible in electronic image products. Images are produced from the best available original document.}




\section{Table of Contents}

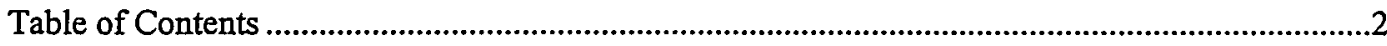

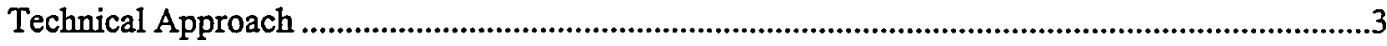

Product Identification and Description...........................................................................3

Technical Milestones and Product Development Needs for Commercial Success .......................4

Product Compatibility with Building Industry and Energy Savings Potential .............................4

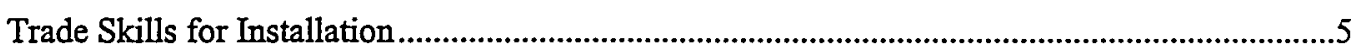

Phase 2: Product and Business Development....................................................................6.6

Task 1: Product Development and Testing ......................................................................6

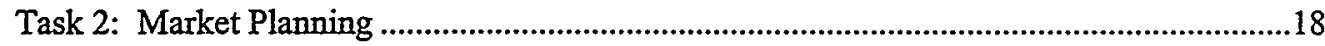

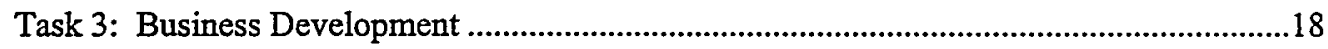

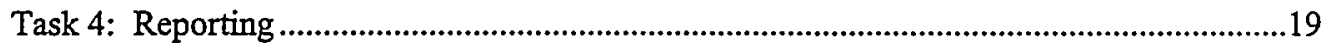

Phase 3: Product Demonstration and Code Approval ..........................................................20

Task 1: Product Demonstration and Verification ...............................................................20

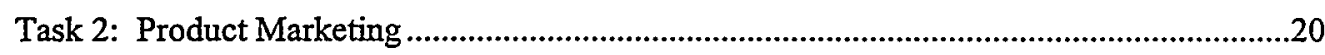

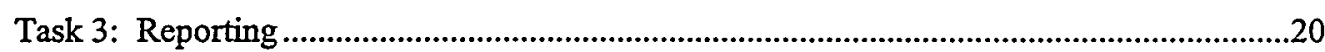

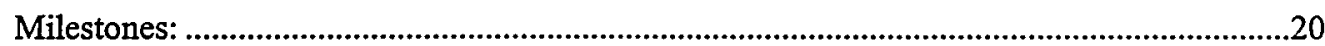

Applicant and Participant Roles, Capability and Organization .............................................20

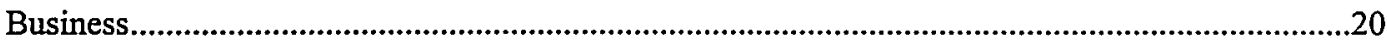

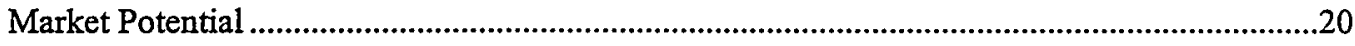

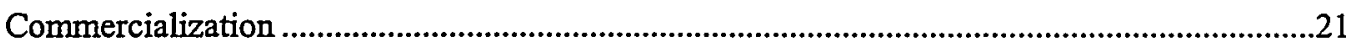

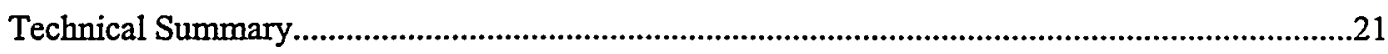

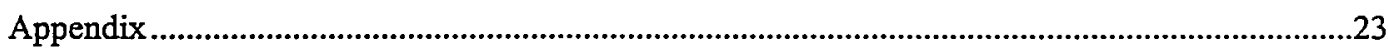

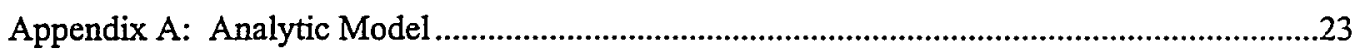




\section{Technical Approach}

The expansive flat rooftops of industrial and commercial buildings across America offer the largest, most secure, and potentially least-cost "real estate" opportunity to install massive amounts of solar photovoltaic generation in the building sector. Unfortunately, mechanical penetration of roofing membranes is very expensive and perceived by building owners and operators to increase the likelihood of leaking. In response Ascension Technology has pioneered the development of low-cost ballasted approaches for mounting PV arrays. Recently, however, we have experienced our first two instances in which strong winds have moved our arrays on rooftops and heightened our interest, and the PV industries' need, to develop zero-penetration mounting techniques that are more secure, yet remain low in cost.

In this PV BONUS project, Ascension Technology and its partners addressed wind loading on solar panels and the suitability of using frictional forces between ballast trays and roofing materials to resist PV arrays sliding on rooftops. The primary goal of the project is to capture the potential cost savings made possible by ballast-mounting by showing under what conditions it can satisfy wind loading concerns. A secondary goal is to address a more geographically constrained concern regarding withstanding seismic forces.

Under Phase 1 we increased our understanding of wind forces on roof-mounted arrays using improved analytical tools, developed a force-measuring instrument and began to take PV array wind force measurements in the field. The success of Phase 1 launched the investigation of wind speed limits for the use of ballast mounting PV arrays on flat roofs using analytical methods and the development of instrumentation for gathering quantitative field performance data.

The successful completion of Phase 2 includes the validation of the analytic methods for predicting wind speed thresholds for ballasted PV arrays to prevent sliding and overturning of the arrays. An analytic model has been developed to guide the configuration of arrays and a means to improve the frictional resistance of ballast mounted trays has been developed. Under Phase 2 we developed and tested a new array attachment concept as an improvement to our traditional ballast tray products.

Ultimately (and hopefully), a successful Phase 3 will see these low-cost, zero-penetration methods accepted by building code officials and by the roofing industry and appealing for retrofit applications by "Green" companies.

\section{Product Identification and Description}

Since 1992 Ascension Technology has installed photovoltaic (PV) arrays on the flat roofs of schools, office buildings, factories and warehouses across the country in the course of its PV projects for the U.S. Environmental Protection Agency and the U.S. Department of Energy. Early in this process we found that code compliance is among the most significant challenges to the process of reducing the cost of installing PV systems. Since that time we have, with DOE support, led the PV industry in the development of PV systems that use Underwriters Laboratory listed components and are in "letter of the law" compliance with the National Electrical Code. For example, we assisted in getting Underwriters Laboratories first listings for power converters for grid-interconnected systems and for our photovoltaic source circuit protectors and have recently obtained the first listing for a fully integrated ac module, our SunSine ${ }^{\otimes} 300 \mathrm{AC}$ module developed under NREL's PVMaT program. A remaining code barrier to low cost integration of PV onto flat roofs involves gaining a much better understanding of the forces and moments on roof-mounted arrays. Inexpensive PV support structures holding panels at optimal-energy-producing tilt angles 
and row-to-row spacing to withstand these wind driven forces and moments are needed for PV installations on buildings to achieve their full potential.

In the United States, flat roofs on commercial and industrial buildings account for onethird of the nation's 10 billion square meters of roof area (about 3,700 square miles, or more than half the size of the State of Connecticut). Residential buildings account for the remaining twothirds. After accounting for the pitches and orientations of residential roof-tops, the potential electric generation capacity for solar panels on pitched and flat roof buildings is about the same, about 150 gigawatts for each type of roof. Were all this available roof area devoted to solar power generation, it would provide about $20 \%$ of the nation's electricity.

In a report to the DOE Office of Building Technologies, Arthur D. Little indicates that Ascension Technology's ballasted array mounting approach offers " . . . significant cost reduction potential"' relative to making structural connections to building structure. The report identifies two major concerns with this approach to mounting PV arrays: seismic concerns as related to the Uniform Building Code (1991) section 2336 and wind forces, insofar as there is no uniform guidance to assess the wind pressures on roof-mounted solar panels.

The Ascension Technology ballasted flat roof mounting system includes two basic components: a sheet metal ballast tray approximately four by six feet in size and a riser mounting bracket that supports the edge of a PV panel assembly. Ascension Technology's array-mounting products are fabricated using galvanized sheet steel. Early installations during the first round of systems for the U.S. EPA in 1993 had the arrays mounted at 15 degrees from horizontal, but in subsequent installations the angle was increased to 25 degrees. The steeper angle improves snow shedding and annual energy production, at the expense of increased wind loading.

\section{Technical Milestones and Product Development Needs for Commercial Success}

For Phase 2 we had two critical milestones. First was the preparation of a definitive analysis and summary of field performance measurements for wind-force loading on PV arrays mounted on flat roofs. Second was the development and testing of a low cost array-mounting product that is clearly acceptable for the vast majority of the $3+$ billion square meters of flat roofs in the United States.

With increasing national attention focused on the installation of solar PV systems on rooftops ${ }^{2}$, it is now imperative that reliable and cost-effective products to attach PV arrays to flat-roof buildings become commercially available and are accepted by building code officials. The sooner a credible (to building inspectors) analysis and confirming measurements can be produced, the sooner systems can be installed widely with acceptable array mounting and structural balance-ofsystem cost.

\section{Product Compatibility with Building Industry and Energy Savings Potential}

Our intent is to develop an array-mounting product compatible with most types of singleply roofing systems including EPDM, modified bitumen, and Hypalon/CPE systems that

1 "Building-Integrated Photovoltaic (BIPV) Analysis and U.S. Market Potential", NREL/TP-4727850, Golden, CO, February 1995

.$^{2}$ DOE Press Release, June 27, 1997 
collectively account for 80 percent of the roofing used in the Northeast and Midwest and $20-40 \%$ of the roofing in the South and West. We note that Southwestern U.S. roofs are typically not strong enough to allow for ballast in sufficient amounts and that in many of these cases nonfrictional means to adhere array mounting structures to roofs will be required. This also applies in areas of California where the ballasted approach is also limited by seismic code considerations.

\section{Trade Skills for Installation}

We have found that our ballasted mounting technique is readily understood by roofing contractors and laborers. Typically the use of chalk lines and templates allow the completion of the "heavy" work of installing the trays and adding the ballast before the more mindful work (with the potential for costly accidents) of installing the PV panels begins. As part of our Phase 2 activities, we have simplified this step further with the addition of tray-connectors, which aid in the layout of the trays. Once the trays, jacks and panels are in place electricians are employed to install PV Source Circuit Protectors and to quick-connect them to the source circuits, but this aspect of the installation is already compliant with all codes and standards and is beyond the immediate scope of this project. The tray, jack and panel installation processes each allow for rapid installation of PV arrays. For example an experienced engineer from Ascension Technology, plus a roofing crew foreman with a crew of four plus an electrician can easily install a $25 \mathrm{~kW}$ array in 8 hours. Once PV becomes more common and improved designs and installation tools are available, a six-man crew might install a $50 \mathrm{~kW}$ system in one day. 


\section{Phase 2: Product and Business Development}

During Phase 2, the test apparatus designed in Phase 1 was employed to evaluate the wind loading characteristics on flat roof-mount solar arrays. The empirical test results were used to determine the improved wind resistance of the systems based on redesigning the traditional ballast-mounting system. The results were then applied to an analytic model that was used to assess the ballast required to prevent sliding and overturning of the modules based on the site, module characteristics, and wind speed. The model provides a means to validate the increased wind resistance of the ballast mounted PV arrays with the enhanced design. The redesigned mounting system was then physically tested to verify the results of the modeling exercise and provide a basis for industry acceptance. The final steps of Phase 2 included commercial product introduction and preparation of a marketing and commercialization plan.

\section{Task 1: Product Development and Testing}

\section{Development of a test and acceptance plan for the commercial product}

In the first part of the product development task, field tests were conducted to assess the effects of wind loading on modules in a ballast-mounted array. The tests included the determination of coefficients of friction for different roof types and the calculation of coefficients of pressure on modules by position in the array and by wind direction. The results of the tests were incorporated into an analytic model used to calculate the factor of safety from sliding and overturning of modules exposed to high winds. The model has been constructed such that the user may adjust the module and site characteristics of a roof-mounted array and determine the ballast required to prevent sliding and overturning in the worst-case scenario based on the factor of safety desired.

In the second part of the product development task, a modification to the roof-tray, ballastmounting system used by Ascension Technology was designed based on the results of the fieldtests and analytic model. A prototype system was fabricated and subjected to pull tests to verify the improvement gained with the new design.

\section{Measurement of Coefficient of Friction on Available Roof Types}

The positive (downward) normal force on the module (weight of module and ballast less the vertical wind force) and the coefficient of friction between the ballast and the roof membrane prevent the modules from sliding along the roof. Allowable ballast weight averages approximately 15-20 psf. As the ballast weight cannot be infinitely increased, improvement in the coefficient of friction is also required to increase resistance of the modules to sliding. In order to assess the achievable coefficients of friction, the trays were tested on common roof types.

Tests on the sliding friction resistances of ballast-mounted trays were conducted on EPDM and tar and gravel roof types. The tests, as designed in Phase 1, included a strain gauge measurement of $1 / 4$ scale trays pulled on the different roof types with added ballast ranging from 0 to 40 pounds. In addition, Ascension Technology improved the coefficient of sliding friction of the roof tray by adhering a layer of neoprene to the bottom of the tray. As shown in Figure 1, the addition of neoprene significantly increases the coefficient of friction on both roof types.

Figure 1: Measured Coefficient of Friction by Roof Type, With and Without Neoprene

\begin{tabular}{|l|c|c|}
\hline & & \\
\hline & Neoprene & Cofficient of Friction \\
\hline Roof Typey & Bare Tray \\
EPDM & Adhered Tray & \\
\hline Tar and Gravel & $0.8-1.0$ & $0.4-0.5$ \\
\hline
\end{tabular}


In the future, Ascension Technology will continue to research means to further improve the coefficients of friction and therefore, to prevent sliding with lower required ballast weight.

\section{Wind Force Testing and Determination of the Coefficient of Pressure}

in order to validate the coefficient of pressure values used in the analytic model, wind force tests were conducted on a single module mounted on a rooftop and prior results on scale model in a wind tunnel were incorporated in our analysis. The results of the tests showed that the pressure coefficients are highest on south-facing modules directly exposed to northeast and northwest winds (the corner modules on the perimeter of an array in the northern hemisphere). The pressure coefficient is lower in the middle of a single module or a row of modules and lowest at the "downwind" end.

We conducted wind force tests on a single module at a coastal location in Newburyport, MA (approximately 40 miles from our Waltham offices), where we had already installed a 10meter wind tower and with ready access to a datalogger and phone line. The wind force measurement instrument, developed and described in Phase 1 was moved from our Waltham, MA, office rooftop to this location during April 1998. Ascension Technology is continuing to collect data on this system, including the wind speed and direction and resultant forces and moments at one end of the module. The force measurements were used to calculate the average coefficient of pressure on the module due to winds from different directions, with the following equation:

$C p=\frac{p}{1 / 2 \rho V^{2}}$, where $p$ is average pressure, $p$ is the density of air and $V$ is the wind speed

The convention used to describe wind direction on a south-facing module puts south at $0^{\circ}$ and East at $90^{\circ}$, as described in Figure 2. The forces on the module were only measured on the east side of the module. The highest coefficient of pressure was calculated in the exposure of the module to winds from the North East between 110 and 140 degrees. The coefficient of pressure in this case has been measured as approximately 1.75 .

\section{Figure 2: Wind Direction Convention Used in Analysis}
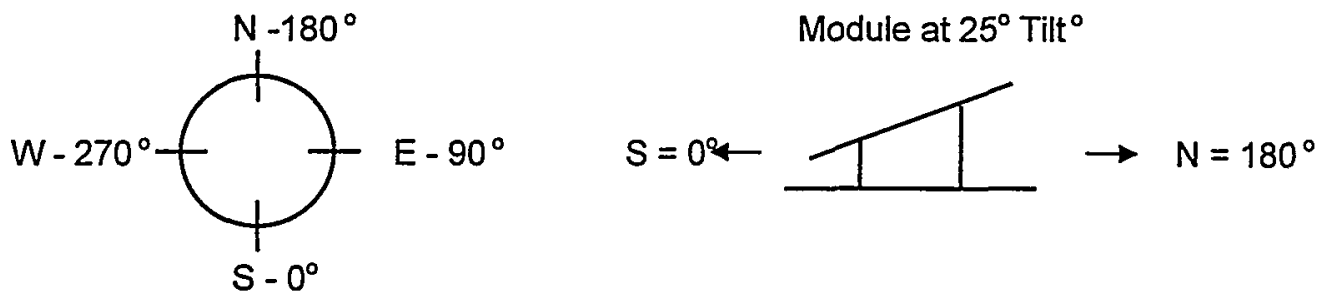

In addition, Professor Robert $E$. Akins reviewed wind-tunnel studies of wind forces on solar collectors in different configurations and performed further analysis to provide an estimate of the expected coefficients of pressure on typical Ascension Technology configurations. In this test, the data on forces on experienced by the modules in the western column of the array and in the center of the array were presented. Thus, the pressure coefficients calculated for the modules on the west side, due to winds from $0-180^{\circ}$ represent the wind effects on shielded modules and pressure coefficients on the modules on the west side due to winds from $180-360^{\circ}$ represent the exposed modules. The highest coefficient of pressure was calculated on the northwest corner module exposed to winds from $210^{\circ}$. Due to symmetry, it can be assumed that the northeast corner exposed to a $150^{\circ}$ wind would experience the same force.

The data resulting from the field tests on the single module and from the wind tunnel tests indicate that there is a proportional decrease in the coefficient of pressure on the modules from the exposed to the shielded side. Comparison of the proportions also indicates that the middle of the single module and the center modules of the array behave similarly, with a center experiencing a coefficient of pressure $70 \%$ of an exposed module and the shielded module experiences a coefficient of pressure approximately $40 \%$ of the exposed module. This was used to estimate the coefficients of pressure and relative stability of the modules. The pressure 
coefficients of the exposed, center and shielded modules in a three row array exposed to $210^{\circ}$ wind, considered the "worst case" scenario, are shown in Figure 3. These figures are calculated based on an array constructed on a one-story building, corrected for modules at a $30^{\circ}$ panel tilt. As this describes the worst case wind loading, these figures are applied to an analytic model describing the vulnerability of the modules to sliding and overturning in high wind conditions.

Figure 3: Pressure Coefficients Calculated for Exposed and Center Modules in 3 -Row Array Exposed to Wind at $210^{\circ}$ Wind at $210^{\circ}$

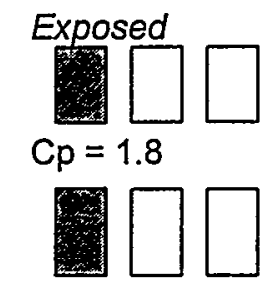

$\mathrm{Cp}=0.50$

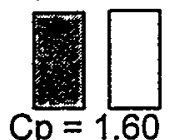

$\mathrm{N}-180^{\circ}$

Center

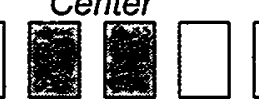

$0 \mathrm{Cp}=1.26$

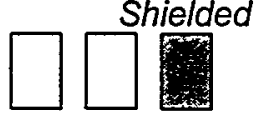

Single Row

or North Row

$\mathrm{Cp}=0.72$

Center Row

$C p=0.35$
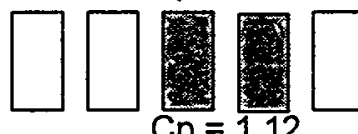

$\mathrm{Cp}=1.12$

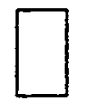

$\square$ 政

$\mathrm{Cp}=0.20$

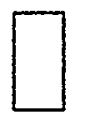

South Row

Analytic Model of Wind Resistance

An analytic model was constructed to assess the risks of modules at different positions in an array to sliding and overturning due to variable wind speeds and directions. The model allows the user to input the site and array characteristics and array configuration, as shown in Table 1.

\section{Table 1: User Inputs in Analytic Model of Effects of Wind Force}

\begin{tabular}{|l|l|l|}
\hline Input & & \\
\hline Site Characteristics & WS & Mph \\
\hline Exposure Category & & \\
\hline Basic Wind Speed & $\mathrm{h}$ & $\mathrm{ft}$ \\
\hline Building Category & & \\
\hline Height of Roof Above Ground & & \\
\hline Roof Type & & \\
\hline Array Characteristics & $\mathrm{H}$ & $\mathrm{ft}$ \\
\hline Tray Surface & $\mathrm{T}$ & Degrees \\
\hline Minimum Panel Height Above Surface & \\
\hline Panel Tilt Angle & & \\
\hline Type of PV Module & Apv & sq. ft. \\
\hline PV Panel Surface Area & At & sq. $\mathrm{ft}$. \\
\hline Tray Surface Area & Wov & lbs. \\
\hline Weight of Panel and BOS & $\mathrm{N}$ & \\
\hline Array Configuration & Number of Panels (by Row) & \\
\hline Number &
\end{tabular}

Based on the user-input parameters, the coefficients shown in Table 2 are determined from tables given in ASCEIANSI 7-95: Standards for Minimum Design Loads for Buildings and Other Structures. 
Table 2: Values Determined Based on User-Defined Parameters

\begin{tabular}{|l|l|}
\hline Inpuit & Nótation \\
\hline Velocity Pressure Coefficient & $\mathrm{Kz}$ \\
\hline Importance factor & $\mathrm{I}$ \\
\hline Coefficient of Friction & uf \\
\hline
\end{tabular}

The results provide a scientific basis for determining the threshold wind speed and ballast levels at which friction is not sufficient to hold an array in place. The procedures and criteria of ASCE 7-95 "Minimum Design Loads for Buildings and Other Structures" were used in the development of the model. The analysis showed that the safety factor against overturning is always likely to be better than that against sliding at module tilt angles greater than $10^{\circ}$, due to the geometry of the tray and module. Therefore, the analysis in this report is based primarily upon the prevention of sliding. The basic equation used in the calculation of the wind force normal to the module (Fn) is as follows:

$$
F n=K z * C p * 0.00256 *(W S * I)^{2} * A p v
$$

The Factor of Safety (FS) from sliding is a function of the following:

$$
\text { FS (sliding) }=\frac{f *(W b+W p v-E n * \operatorname{Sin}(\square)), \text { where } W b \text { is weight of ballast }}{F n * \operatorname{Cos}(T)}
$$

The ballast required vs. wind speed on a single module as a function of friction coefficients is shown in Figure 4.

Figure 4: Ballast Required by Wind Speed for a Single Module as a Function of Coefficient of Friction

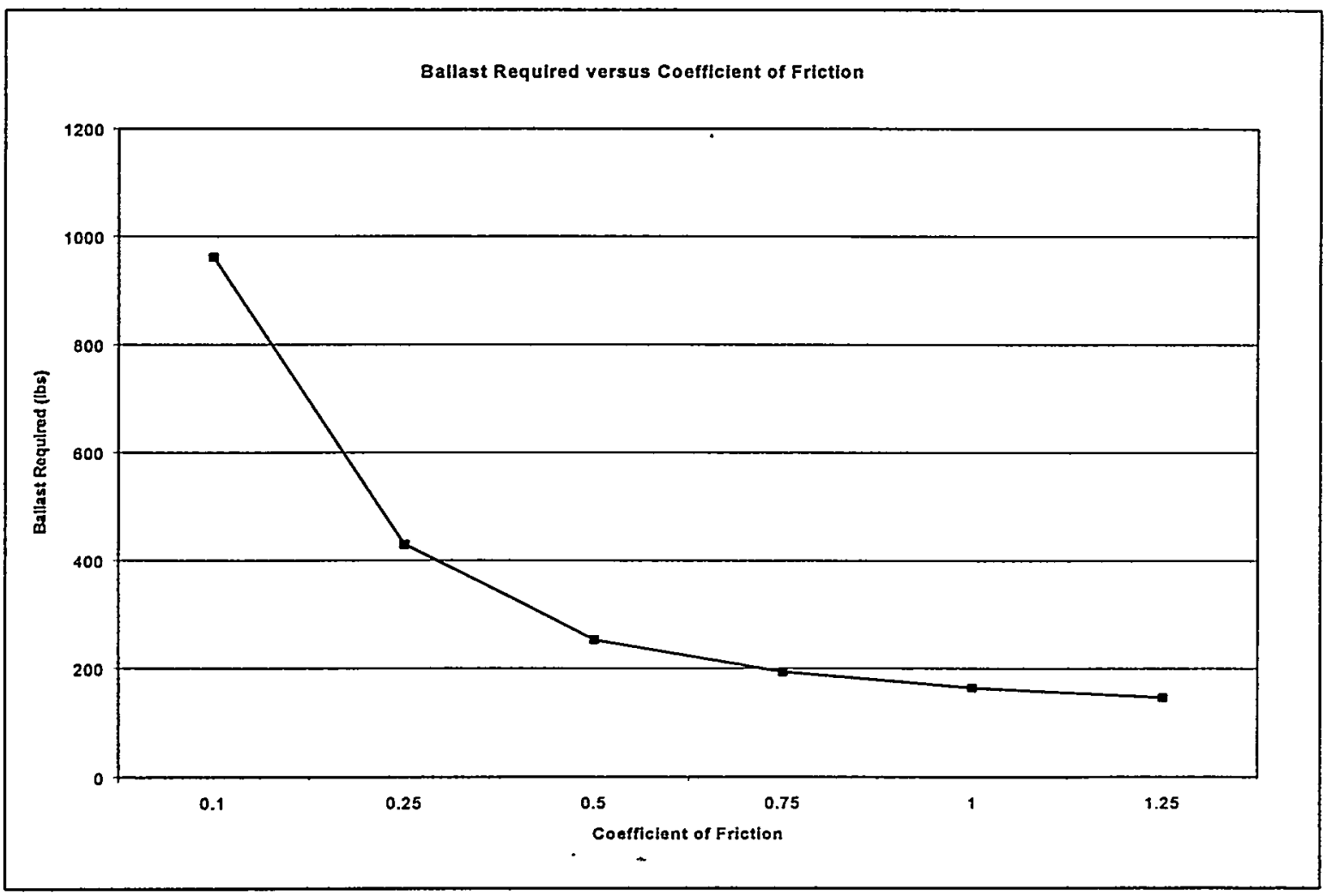


In order to examine different positions in an array, the pressure coefficients were varied according to the results of Akins' study. The "worst case" pressure coefficients, resulting from winds at $210^{\circ}$ were used to examine the relative stability of different module positions within the array exposed to a range of wind speeds. The results of the studies indicate that the unshielded corner modules are extremely vulnerable to northeast and northwest winds. Yet, the coefficients of pressure exerted on the center row of three rows of modules are significantly lower than the pressures on the front and back rows. The differences in the wind pressures among modules in an array is significant enough to warrant stabilizing more vulnerable modules by anchoring them to the more stable modules. Due to the advantage of shielding modules, wherever possible, a minimum of two rows of modules provides an advantage in the installation of the array.

In order to assess the added value of connecting adjacent trays together, the model was enhanced to determine the factor of safety on a unit of interconnected modules, such that each additional module connected to the unit represents a neighboring module with an incrementally lower pressure coefficient. The results of the analysis of the ballast required for 1,4 , and 9 interconnected module arrays at wind speeds from 60 to $100 \mathrm{mph}$ holding the factor of safety at 1.5 are shown in the following chart. The single module represents the most vulnerable module in an array.

Figure 5: Ballast Required by Wind Speed for Interconnected Module Arrays

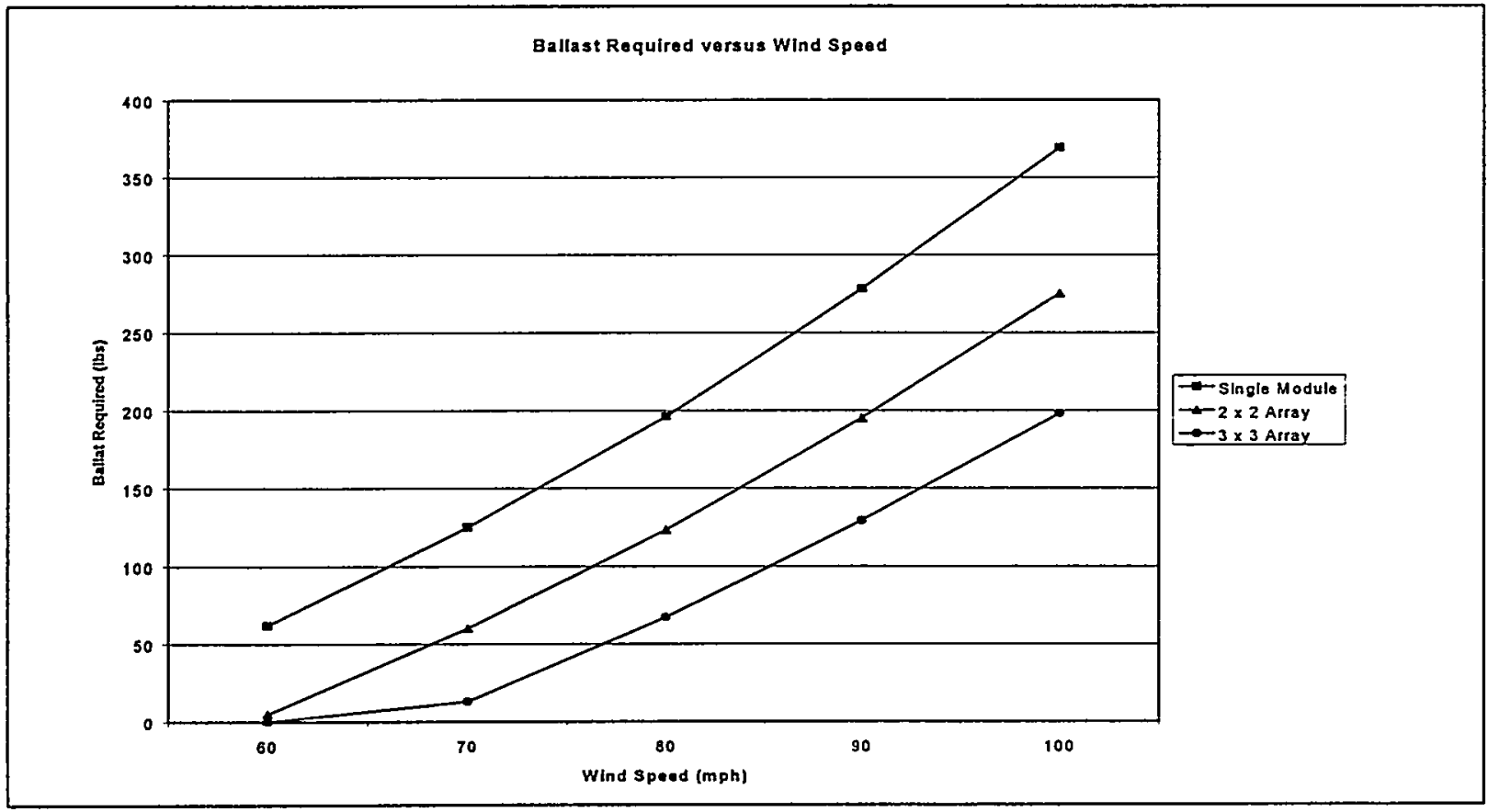

The conclusions of the analysis were used to examine the impact of modifying the mounting design to the overall vulnerability of the array. As a result Ascension Technology has designed a connector which can be used to tie the trays in the original mounting design together. The strategically placed connectors provide the maximum increase in stability to the more vulnerable modules. Thus, the solution significantly improves the stability of the array when exposed to typical high wind speeds of $70-80 \mathrm{mph}$. In addition, resilience from sliding and overturning is increased in higher wind situations.

\section{Product Design}

The tray connector which has been designed for Ascension Technology's ballast mounted roof trays, consists of two pieces. The first piece is a length of aluminum placed at the centers of 
each side of the roof tray to connect the tray to the next tray in each direction. The design also includes a diagonal connector used in the corners for added rigidity.

Figure 6: Illustrative Configuration of Tray Connectors in a Three Row Array

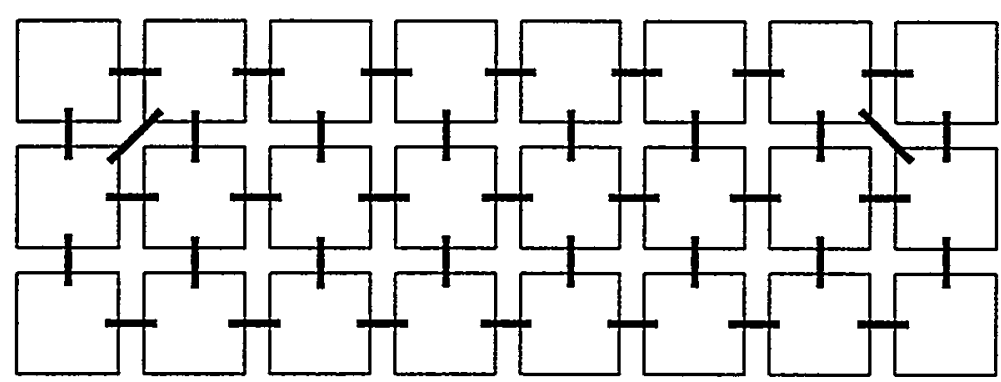

The connector is flanged for added strength. A calculation of the force at which the piece will fail due to elastic buckling, indicates that it will withstand a minimum of $22,000 \mathrm{lbs}$. of axial loading and four times as much if the ends are considered fixed points. See photographs in the appendix.

This low cost solution provides significant resistance of a ballast-mounted array to wind loading with minimal additional parts and installation time. A prototype system was fabricated and subjected to pull tests to verify the improvement gained with the new design according to the test plan given below. 
Test Plan for Performance of Redesigned Ballast Mounted PV Array

Objective:

1. To perform further coefficient of friction tests.

2. To test the performance of the redesigned ballast mounted PV array, including tray connectors.

Background:

The redesigned ballast mounting system includes tray connectors that stabilize the more vulnerable modules in the array and diagonal connectors that add rigidity to the system.

Figure 7: Configuration of Tray Connectors on 6 Module, 8 Roof-Tray Array

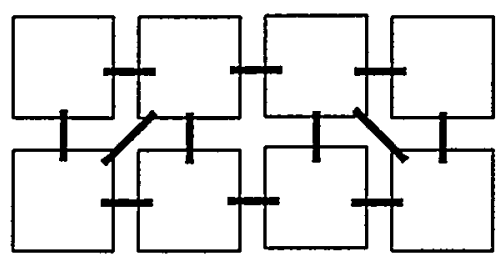

(IIlustrative, not to scale)

An analytic model has been constructed to predict the performance of the redesigned ballast mounting system in a high wind situation. The wind direction and module orientation conventions used in the model are shown in Figure 8.

Figure 8: Wind Direction Convention Used in Analysis

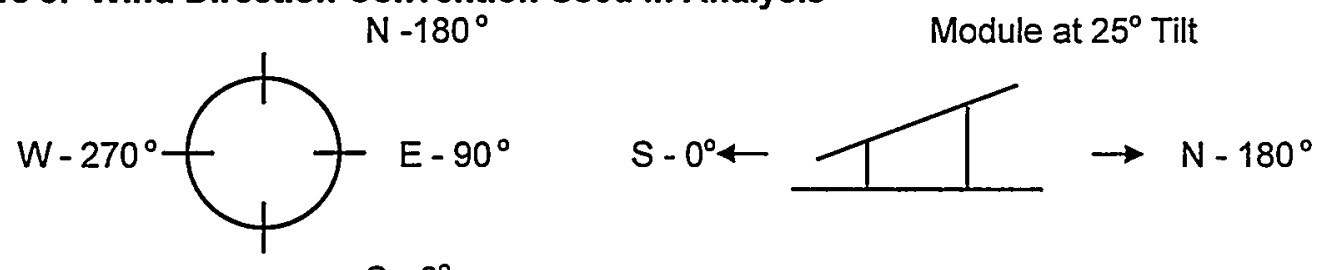

$$
S-0^{\circ}
$$

In the model, the coefficients of pressure resulting from winds at $210^{\circ}$ are used, as this is considered the worst case.

This test of the system will include the application of the horizontal forces on the module configurations shown in Figure 10. The performance of the tray connectors in high loading conditions will be assessed. In this test, the scenario represents sliding on rolled roofing with a layer of neoprene adhered to the roof tray on a roof exposure of Category $B$, at a height of 30 feet and a module tilt of 25 degrees. 
Test Setup:

1. A layer of rolled roofing, approximately $22^{\prime} \times 22 '$, was placed on the parking lot surface at ASE. The roofing was tacked to the parking lot with the use of wood and concrete nails. The roof trays were connected to form an array with the use of "tray connectors."

Figure 9: Test Setup

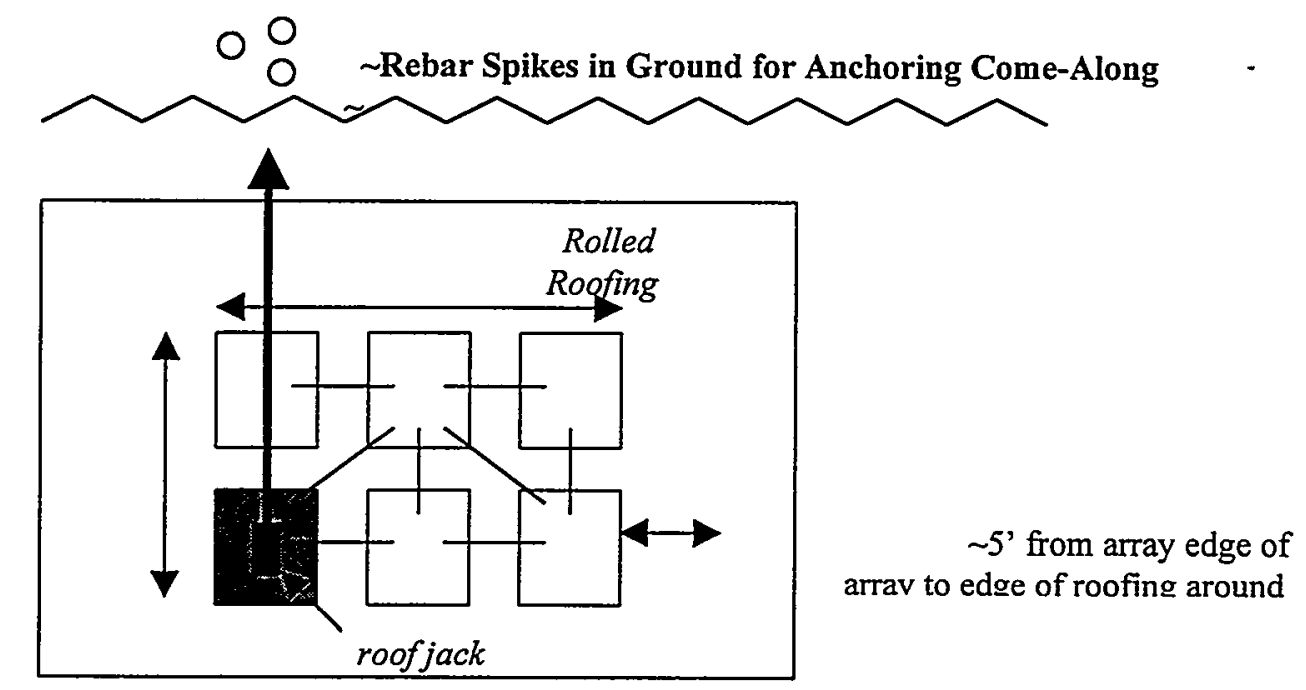

2. A roof jack was used to supply an anchor from which to pull the array. A 2'x4' with an eye bolt was bolted to the roof jack to provide the connector from which to pull. 
3. A pull test on the system was conducted to determine the failure mode of the system. Appropriate ballast was placed on the trays to resemble modules and ballast in an array of the - given size.

Figure 10: Test Procedure

\begin{tabular}{|c|c|c|c|}
\hline Configuration & $\begin{array}{l}\text { Bailast per } \\
\text { Tray } 3\end{array}$ & $\begin{array}{l}\text { Horizontal } \\
\text { Force4 }\end{array}$ & Objective \\
\hline a) & 198 & 177 & $\begin{array}{l}\text { To determine the coefficient of } \\
\text { sliding friction between the tray } \\
\text { and the rolled roofing with } 75 \% \text {, } \\
100 \% \text { and } 125 \% \text { ballast } \\
\text { indicated. }\end{array}$ \\
\hline $\begin{array}{l}\text { With an extra layer of } \\
\text { loose rolled roofing } \\
\text { between tray and }\end{array}$ & 198 & 177 & $\begin{array}{l}\text { To determine whether the } \\
\text { surface between the tray and } \\
\text { roofing or roofing and roofing } \\
\text { slips first. }\end{array}$ \\
\hline c) & 181 & 335 & $\begin{array}{l}\text { To test the tray connectors } \\
\text { without the added rigidity of the } \\
\text { diagonal connector: } \\
\text { 1. Pull to motion of pulled } \\
\text { tray } \\
2 \text {. Pull to distortion of a } \\
\text { tray connector. } \\
\text { 3. Pull to motion of more } \\
\text { than one tray OR } \\
\text { destruction of a tray } \\
\text { connector with up to } 2000 \# \\
\text { force }\end{array}$ \\
\hline d) & 181 & 335 & $\begin{array}{l}\text { To test the added rigidity of the } \\
\text { diagonal connector. } \\
\text { 1. Pull to motion of pulled } \\
\text { tray } \\
\text { 2. Pull to distortion of a } \\
\text { tray connector. } \\
\text { 3. Pull to motion of more } \\
\text { than one tray OR } \\
\text { destruction of a tray } \\
\text { connector with up to } 2000 \# \\
\text { force }\end{array}$ \\
\hline
\end{tabular}

${ }^{3}$ The ballast amount specified refers to the amount of ballast needed to maintain a Factor of Safety of 1 to prevent sliding. A coefficient of friction $\left(\mu_{f}\right)$ of 0.72 has been assumed and may require correction. An additional 55 pounds of ballast on the end trays and 110 pounds of ballast on center trays was required to compensate for the modules. An additional 25 pounds of ballast per tray was required to compensate for the roof jacks. experience.

${ }^{4}$ The force is equivalent to an $80-\mathrm{MPH}$ wind force that an array of the indicated size would 


\section{Test Results} follow.

The pull test was conducted as per the test plan in July, 1999. The results of the test

\begin{tabular}{|c|c|c|c|}
\hline $\begin{array}{l}\text { Configuration and Actual Ballas t Placed in } \\
\text { Tray }\end{array}$ & $\begin{array}{l}\text { Ballast per } \\
\text { Tray (lbs) }\end{array}$ & $\begin{array}{l}\text { Horizontal } \\
\text { Force (Ibs) }\end{array}$ & Notes $\quad \cdots$ \\
\hline $\begin{array}{c}213 \text { - Ballast } \\
90-\text { Tray } \\
17-\text { Roof } \\
\text { Jack } \\
320-\text { Total }\end{array}$ & 213 & 400 & $\mu^{f}=1.25$ \\
\hline $\begin{array}{l}253 \text { - Ballast } \\
90 \text { - Tray } \\
17 \text { - Roof } \\
\text { Jack } \\
360 \text { - Total }\end{array}$ & 253 & 440 & $\mu^{f=1.22}$ \\
\hline $\begin{array}{c}316-\text { Ballast } \\
90-\text { Tray } \\
17 \text { - Roof } \\
\text { Jack } \\
423 \text { - Total }\end{array}$ & 316 & 520 & $\mu f=1.23$ \\
\hline $\begin{array}{l}\text { With an extra layer of } \\
\text { loose rolled roofing } \\
\text { between tray and roofing }\end{array}$ & 316 & 320 & $\begin{array}{l}\text { The rolled roofing slipped at } \\
320 \mathrm{lbs} \text {., moved with very } \\
\text { little force after overcoming } \\
\text { static friction. }\end{array}$ \\
\hline $\begin{array}{l}(2),(3),(4) \\
181-\text { Ballast } \\
55 \text { - Module } \\
17-\text { Roof Jack } \\
253 \text { - Total }\end{array}$ & 181 & 900 & $\begin{array}{l}600 \mathrm{lbs} .: \text { Free corner of tray } \\
\text { (1) begins lifting } \\
800 \mathrm{lbs} \text {.: Distortion of lip of } \\
\text { tray, and tray connector } \\
\text { between trays (1) and (2) } \\
\text { begins to bow } \\
900 \mathrm{lbs} .: \text { Trays (1) and (2) } \\
\text { begin sliding }\end{array}$ \\
\hline $\begin{array}{c}(3),(4) \\
181-\text { Ballast } \\
55-\text { Module } \\
17-\text { Roof Jack } \\
253 \text { - Total }\end{array}$ & 181 & - & $\begin{array}{l}\text { The force is eased and } \\
\text { reapplied, but the trays are } \\
\text { not reset from last test: } \\
800 \mathrm{lbs:} 25-50 \% \text { of tray (1) } \\
\text { is lifting } \\
1000 \text { lbs.: Majority of tray } \\
\text { (1) is lifting and bending }\end{array}$ \\
\hline
\end{tabular}




\begin{tabular}{|c|c|c|c|}
\hline $\begin{array}{l}\text { Configuration and Actual Ballast Placed in } \\
\text { Tray }\end{array}$ & Ballastper & $\begin{array}{l}\text { Horizontal } \\
\text { Force (Ibs) }\end{array}$ & Notes \\
\hline $\begin{array}{c}\text { (2), (3), (4) } \\
\text { 181- Ballast } \\
55 \text { - Module } \\
\text { 17- Roof Jack } \\
253 \text { - Total }\end{array}$ & 181 & 800 & $\begin{array}{l}400 \text { lbs.: Tray (1) slides } \\
\text { and system locks up } \\
600 \text { lbs.: Free corner of tray } \\
\text { (1) begins lifting, connector } \\
\text { between trays (1) and ( } 2 \text { ) } \\
\text { and diagonal connector } \\
\text { begin to bow } \\
800 \text { lbs.: Trays (1) and (2) } \\
\text { begin sliding, and diagonal } \\
\text { connector distorts at } \\
\text { connection points } \\
\text { Force is released and } \\
\text { reapplied } \\
800 \text { lbs.: Trays (1) and (2) } \\
\text { sliding, } \\
\text { connector between trays (2) } \\
\text { and (3) bends as tray } 2 \text { is } \\
\text { pulled away }\end{array}$ \\
\hline $\begin{array}{l}\text { Same as above, except the diagonal } \\
\text { connector is replaced with a diagonal with the } \\
\text { ends pinched in. } \\
\text { (2), (3), (4) } \\
\text { 181-Ballast } \\
55 \text { - Module } \\
17 \text { - Roof Jack } \\
253 \text { - Total }\end{array}$ & & & $\begin{array}{l}400 \text { lbs.: Corner of tray } 1 \\
\text { begins to lift } \\
760 \text { lbs.: Entire corner of } \\
\text { tray } 1 \text { is lifting and the } \\
\text { diagonal is holding, but } \\
\text { beginning to bow } \\
900 \text { lbs.: Trays (1) and (2) } \\
\text { begin to slide, and continue } \\
\text { to slide with } 800 \text { lbs. force. } \\
\text { The diagonal piece is } \\
\text { distorted. }\end{array}$ \\
\hline
\end{tabular}




\section{Guidelines}

Ascension. Technology has compiled guidelines to assist in the design of ballast-mounted PV systems. In addition to the use of the wind resistance model, to determine the minimum ballast required, the following guidelines should also be taken into consideration in the design and installation of the PV system.

1. Small pea size roof ballast should be avoided when installing a PV system. The small ballast is vulnerable to wind and tends to strike and crack the panels.

\section{Identification of resource requirements to carry out the product development and testing plan}

Ascension Technology is routinely designing and installing PV arrays for utility and government customers and routinely installing instruments for remote data acquisition. The technical resources and skills in house were used to complete this activity.

\section{Fabrication and testing of a scalable system-level design}

Ascension Technology has worked with Boston-area metal fabrication shops to manufacture a wide variety of PV and instrumentation related products. These products range in size from our simple RoofJack mounting brackets for pitched roofs to the large ballast trays for our present flat roof mounting designs. We continued to work with local metal fabricators for the prototyping activities.

\section{Development of a production plan for demonstration and market entry}

For initial market entry we will continue to work with Boston area manufacturing job shops. However, during Phase 3 we will plan to identify fabrication facilities close to our markets, which we anticipate will include many of the western states. Accordingly, during Phase 3 we expect to identify a job shop production facility in the Denver metropolitan area, close to our Boulder, Colorado office.

\section{Development of technical and institutional milestones to assure market acceptance}

The key to market acceptance of our array mounting products is clear and unequivocal compliance with building codes. Working with our consultants Jefferson Shingleton and Robert Akins we will focus our efforts on the International Building Code (IBC) that is being developed for implementation beginning in the year 2000. In particular we will attempt to develop products that can be assessed using methods of analysis developed in ASCE 7-95 "Minimum Design Loads for Buildings and Other Structures" as this standard (and its successors) will be referenced by the IBC.

\section{Estimate of the technology validation support from NREL and/or Sandia}

We believe that it would be useful for us to deploy our test unit at the National Wind Test Center at Rocky Flats, Colorado. We understand that this site encounters frequent extreme wind events during the winter and spring months. For this test we will use staff from our Boulder office to install and operate the instrument. NREL could provide us useful support in characterizing the local wind conditions. 


\section{Task 2: Market Planning}

\section{Development of a market entry strategy}

As a leading systems integrator and project developer, Ascension Technology can create a significant market for its own products. Through industry contacts we have also developed markets for our mounting and wiring equipment with many of the leading US manufacturers of photovoltaic panels, including ASE Americas, Siemens, Solarex, and AstroPower. One way that Ascension Technology will assure a ready market for its flat-roof array mounting products is to manufacture mounting rails for the most popular modules from the leading manufacturers. These mounting rails will be configured with Ascension Technology's standard mounting pin assemblies to make it easy for smaller system's integration companies to use our array mounting and wiring products for their installations.

In addition to being a National member of the Solar Energy Industries Association, Ascension Technology is a founding member of the regional New England SEIA and a member of Colorado SEIA. In both regions we have been actively serving the needs of systems installers, initially with our SunSine ${ }^{T M} 300 \mathrm{AC}$ photovoltaic panels and mounting hardware.

\section{Identification of education and training needed for success market entry}

We will engage roofing manufacturers and building code officials in the interpretation of the analytical and experimental work with intention of gaining acceptance for our mounting products.

\section{Task 3: Business Development}

\section{Team development for commercial product introduction}

Ascension Technology's team is limited to our own staff and our two consultants. However, our affiliations with numerous manufacturers of photovoltaic panels who are our vendors and utility and power marketers who are our customers extends our "team" in a commercial sense. We expect that our business will continue to grow along these lines as we develop additional means to simplify the installation of PV arrays on flat roof buildings.

\section{Individual and organizational responsibilities}

Ascension Technology is recognizing a shift in its business from a project-oriented to a product-oriented business. This transformation recognizes the emergence of a real, rather than research and development, market for grid-interconnected PV systems. Accordingly Ascension Technology began in 1997 to establish a product-based manufacturing and accounting system. During 1998 we anticipate continuing to restructure the company to reflect this growing part of the business, particularly with growing "outside" sales of array mounting and wiring equipment.

\section{Development of business and finance plan}

Ascension Technology has not traditionally engaged in major investment decisions. Our business has grown gradually over time without infusion of outside capital. Our growth has 
evolved in response to customers needs and has been sustained by ever increasing demand for our products.

Although we have considered investment in production facilities, we have remained a "virtual" manufacturer for over eleven years by using job shops for all our physical manufacturing, with the exception of our instrumentation final assembly. Without outside funding sources we could continue along this same path or we could consolidate our work by building a PV BOS manufacturing facility. At this point in time the size and dispersed nature of the market suggest that following Phase 3 we should continue to operate in the same way (using job shops) as in the past.

Our current business planning for obtaining investment contributions is focused on strengthening the marketing and administrative aspects of the company, rather than on our own internal manufacturing. Should markets proliferate and our marketing succeed (as we all hope), Ascension Technology will then revisit the issue of establishing integrated manufacturing facilities at locations near our best market areas. Currently we believe that potential opportunities for such manufacturing exist in Massachusetts and Colorado.

\section{Task 4: Reporting}

\section{Final project review at completion of Phase 2}

With our Phase 2 effort completed, we anticipate that our final project review for Phase 2 will be held during the September-December, 1999 period. We are in the process of submitting a proposal for Phase 3, with the objective of bringing the project to completion through product demonstration, verification, and marketing. 


\section{Phase 3: Product Demonstration and Code Approval}

\section{Task 1: Product Demonstration and Verification}

Phase 3 efforts will be aimed at field tests and market demonstrations of the zero penetration systems, performance monitoring of installations, refinement of product manufacturing methods, education/training of construction-industry professionals and code officials and finalizing business plans and relationships.

Fabrication and initial field testing of production units will occur during the first six months of the Phase 3 project. This will include test and acceptance of the commercial product in the field with real customers, roofing vendors, and building inspectors. Demonstration and verification to verify technical and economic performance will be accomplished through the installation of twentyfive $20 \mathrm{~kW}$ rooftop installations at locations across the United States.

\section{Task 2: Product Marketing}

Finalization of commercial team relationships will result from the marketing and installation of the twenty test systems. The introduction of the product into the market will also follow from this set of high visibility installations. Implementation of an education and training program will accompany each of the installations so that building trades, building code officials and building operators across the nation will be exposed to Ascension Technology mounting and wiring products.

\section{Task 3: Reporting}

A kickoff meeting will be planned following Phase 3 award, perhaps in conjunction with the Phase 2 final report. Annual project review meetings and a final report will be given near completion of Phase 3 Product Demonstration and Marketing . : Product Demonstration and Marketing: Product Demonstration and Marketing

\section{Milestones:}

Our schedule calls for all tasks to be complete 18 months after start of Phase 3

\section{Applicant and Participant Roles, Capability and Organization}

Dr. Kern will be serve as the principal investigator for the project.

\section{Business}

\section{Market Potential}

The market sectors for Ascension Technology's flat roof mounting systems includes institutional (i.e., schools), commercial and industrial roof tops because such roofs tend to be large and flat. 
Because flat roof buildings are much less likely to be shaded areas, the overall potential capacity (and PV market potential) in the commercial and industrial sector is equal to the potential on residential buildings. Commercial office buildings are particularly well matched to PV because their demand profiles are typically coincident with the peak solar power availability during peak, summer time electric demand periods when electricity has its highest value. Based on statistics of building roof areas there is the potential to install about 140 gigawatts of PV capacity on commercial and industrial buildings in the United States. Assuming four ballast trays per kilowatt, the U.S. market-potential for effective ballast trays and flat roof jacks appears to be approximately 500 million pieces.

Such a market could provide approximately $15 \%$ of the approximately $2 \times 10^{12} \mathrm{kWh}$ of electricity used annually in the U.S. by commercial and industrial customers. Since coal-fired generation produces about $0.5 \mathrm{~kg}$ of $\mathrm{CO}_{2}$ emissions per kilowatt-hour of power generated, this $15 \%$ could save as much as $300 \times 10^{9} \mathrm{~kg}$ of emissions annually, about $5 \%$ of the U.S. total.

\section{Commercialization}

Since the late 1970s Ascension Technology's principals have been at the forefront of roofmounted PV systems across the U.S. Our approach to commercializing our mounting and wiring equipment has been to use it in our own projects and to sell components to other PV system integrators. As examples of wiring equipment we cite the use of our PV Source Circuit Protectors ${ }^{\top M}$ by PhotoComm for their Superior Valley system and by Whiting-Turner for the Olympic Pool project in Atlanta. For array mounting we cite Solar Design Associates use of our ballast trays at the Union of Concerned Scientists in Cambridge.

Ascension Technology uses outside fabricators for manufacturing its balance-of-systems system components. Accordingly. we have minimal capital requirements for machinery. Our business revenues have been growing faster than the PV industry as a whole and our working capital needs have been met through customer progress payments. We do not envision any difficult maintaining our $30-50 \%$ growth continuing to use this approach to financing our activities.

Ascension Technology's marketing and sales efforts are founded on our leadership position in the rooftop, grid-connected PV systems business. Those installing grid-connected PV systems are usually aware of our capabilities and contact us when they have needs for our balance-of-systems products. We intend to maintain our high visibility in the grid-connected marketplace through our participation in the TEAM-UP, PV BONUS and PVMaT programs as both a prime contractor and as sub-contractors.

\section{Technical Summary}

Ballast-mounting techniques are among the least cost means to attach PV arrays to flat roofs on commercial and industrial buildings. Only frictional and gravitational forces at the interface between the ballast tray and the roofing membrane resist winds forces that can slide or overturn such arrays. Ascension Technology has pioneered the development and experimental application of these mounting techniques, but there are major remaining concerns as to their longterm acceptability under the codes governing building construction in the U.S.

In Phase 1 of this project Ascension Technology developed the analytic and experimental capabilities for quantifying the balance between driving (wind, seismic) forces and the restraining (gravitational/frictional) forces that must exist for the ballast-mounting approach to succeed. In Phase 2 we exercised these capabilities and improved our ballast-mounting approaches. In 
Phase 3, which we envision beginning in late 1999, we anticipate a significant commercial market for flat-roof-mounted PV arrays to support our market demonstration activities.

The organizations involved in this project are all located in the Commonwealth of Massachusetts. The only pre-existing agreement between any of the parties pertains to the PVMaT 4a agreement between Ascension Technology and ASE Americas. Under this agreement ASE has granted Ascension Technology approximately $\$ 90,000$ in cost shared laminate development and testing services in return for Ascension Technology's agreement to use ASE modules with our modular scale inverter for three years starting in January 1995. 


\section{Appendices}

\section{Appendix A: Analytic Model}

The PV Bonus analytic model developed at Ascension Technology is based on the reference, ANSI/ASCE 7-955. The following describes a step by step approach to using the reference source as a basis for wind analysis on PV modules. The equations and reference tables are taken directly from the ANSI/ASCE 7-95.

\section{Determine the Input Parameters}

1. The basic wind speed is determined using the map provided as Figure 6-1 of ANSI/ASCE 795. The values represent 3 -second gust speeds in miles per hour at 33 feet above ground for Exposure $\mathrm{C}$ category and are associated with an annual probability of 0.02 .

2. The exposure category is determined based on descriptions given in Section 6.5.3 as shown below.

\section{Section 6.5.3: Exposure Categories}

\begin{tabular}{|l|l|}
\hline Exposure A & Large city centers with buildings over 70 feet \\
\hline Exposure B & $\begin{array}{l}\text { Urban and suburban areas, numerous bldgs residential size and larger, } \\
\text { dense }\end{array}$ \\
\hline Exposure C & Open terrain, scattered obstructions less than $30^{\prime}$ \\
\hline Exposure D & Flat, coastal, no obstructions, near water \\
\hline
\end{tabular}

3. Building classification is determined based on Table 1-1 as shown below.

Table 1-1: Classification of Buildings and Other Structures for Wind, Snow, and Earthquake Loads

\begin{tabular}{|l|l|}
\hline Category & Nature of Occupancy \\
\hline II & All buildings, except those listed below \\
\hline III & $\begin{array}{l}\text { Primary occupancy greater than } 300 \text { persons to one area. Buildings that } \\
\text { represent a substantial hazard to human life in the event of failure. }\end{array}$ \\
\hline IV & $\begin{array}{l}\text { Essential facilities, including but not limited to: } \\
\text {-Hospital, medical facilities having surgery or emergency treatment areas } \\
\text {-Fire or rescue and police stations } \\
\text { - Government structures/equipment } \\
\text { - } \text { - } \\
\text {-Pommunication centers or facilities required for emergency response } \\
\text {-Structures having critical national defense capabilities } \\
\text {-Designated shelters for hurricanes }\end{array}$ \\
\hline I & $\begin{array}{l}\text { Buildings and structures with low hazard to human life in case of failure, } \\
\text { such as agricultural, temporary, and minor storage facilities }\end{array}$ \\
\hline
\end{tabular}

${ }^{5}$ American Society of Civil Engineers. Minimum Design Load for Buildings and Other Structures. ANSI/ASCE 7-95. 
4. If the system is roof mounted the building height or the height of the roof above ground is required, and will be used to determine the velocity pressure coefficient of the wind.

5. The roof type (EPDM, Tar and Gravel) must be provided and will be used to determine the coefficient of friction.

6. The tray type is also required for coefficient of friction and the options of a bare tray or a tray to which a layer of neoprene is adhered to the surface are given. The neoprene improves the coefficient of friction between the tray surface and roof.

7. The PV module type may be specified as one of the choices given, which currently includes the following types and their corresponding dimensions. Based on the type specified, the dimensions are determined and the area of the panel, Apv, is calculated.

\begin{tabular}{|cccc|}
\hline $\begin{array}{c}\text { Module } \\
\text { Type }\end{array}$ & $\begin{array}{c}\text { Area, Apv } \\
\text { (sq. ft.) }\end{array}$ & $\begin{array}{c}\text { Length } \\
\text { (inches) }\end{array}$ & $\begin{array}{c}\text { Width } \\
\text { (inches) }\end{array}$ \\
ASE-300 & 26.13 & 74.50 & 50.50 \\
SX-120 & 11.97 & 44.19 & 39.00 \\
BP Solar & 27.54 & 47.00 & 84.38 \\
\hline
\end{tabular}

8. Minimum panel height above the surface refers to the height above ground of the bottom edge of the panel.

9. The angle of the panel tilt relative to the surface on which it is mounted is required.

10. The area of the tray surface must be provided, the common dimensions are 44 inches $\times 79.25$ inches.

11. Weight of panel and BOS must be provided.

12. The user must input the factor of safety to be used in the calculation. As guidance, a factor of safety of 1.5 is generally required. 
Reference the Lookup Tables based on the Input Parameters

13. The velocity pressure coefficient is determined based on the height of the roof above ground and the exposure category from Table 6-3 of the reference source.

ASCE Table 6-3: Velocity Pressure Coefficient, Kh and $K z$

\begin{tabular}{|lllll|}
\hline Height Above & Exposure A & Exposure B & Exposure C & Exposure D \\
Grade (ft.) & & & & \\
0 & 0.32 & 0.57 & 0.85 & 1.03 \\
15 & 0.32 & 0.57 & 0.85 & 1.03 \\
20 & 0.36 & 0.62 & 0.90 & 1.08 \\
25 & 0.39 & 0.66 & 0.94 & 1.12 \\
30 & 0.42 & 0.70 & 0.98 & 1.16 \\
40 & 0.47 & 0.76 & 1.04 & 1.22 \\
50 & 0.52 & 0.81 & 1.09 & 1.27 \\
60 & 0.55 & 0.85 & 1.13 & 1.31 \\
70 & 0.59 & 0.89 & 1.17 & 1.34 \\
80 & 0.62 & 0.93 & 1.21 & 1.38 \\
90 & 0.65 & 0.96 & 1.24 & 1.40 \\
100 & 0.68 & 0.99 & 1.26 & 1.43 \\
120 & 0.73 & 1.04 & 1.31 & 1.48 \\
140 & 0.78 & 1.09 & 1.36 & 1.52 \\
160 & 0.82 & 1.13 & 1.39 & 1.55 \\
180 & 0.86 & 1.17 & 1.43 & 1.58 \\
200 & 0.90 & 1.20 & 1.46 & 1.61 \\
250 & 0.98 & 1.28 & 1.53 & 1.68 \\
300 & 1.05 & 1.35 & 1.59 & 1.73 \\
350 & 1.12 & 1.41 & 1.64 & 1.78 \\
400 & 1.18 & 1.47 & 1.69 & 1.82 \\
450 & 1.24 & 1.52 & 1.73 & 1.86 \\
500 & 1.29 & 1.56 & 1.77 & 1.89 \\
\hline
\end{tabular}

14. The importance factor of the effect of the wind on the panels is based on the building category specified, as shown below in Table 6-2.

ASCE Table 6-2: Importance Factors, I (Wind Loads)

\begin{tabular}{|c|c|}
\hline Building Category & $\begin{array}{c}\text { Importance Factor, } \\
\text { I }\end{array}$ \\
\hline I & 0.87 \\
\hline II & 1.00 \\
\hline III & 1.15 \\
\hline IV & 1.15 \\
\hline
\end{tabular}


15. Ascension Technology staff has experimentally determined the coefficients of friction. The appropriate coefficient is chosen based on the roof type and tray surface. The current values used in the model are shown below.

\begin{tabular}{|lcc|}
\hline Roof Type & With & Bare \\
& Neoprene & \\
Tar and Gravel & 0.73 & 0.38 \\
EPDM & 0.71 & 0.44 \\
Rolled Roofing & 0.72 & 0.41 \\
\hline
\end{tabular}

16. The number of modules in the array must be entered by row. This model only accommodates up to a 3-row array at this time. The first row or a single row will be considered the North row, if a second row is added, it is considered the South row, and the final row is the center row.

\section{Determining the Coefficient of Pressure, $\mathrm{GCp}$}

17. The coefficient of pressure on a panel in the array is dependent on its position in the array. Experimental data supplied by Professor Robert E. Akins ${ }^{6}$, presents the coefficients of pressure on the end and center panels in one, two, and three row arrays exposed to winds from all directions. According to the data, the North row experiences the greatest wind forces, then the South row and finally the center row. Panels at the array edge exposed to the wind experience far greater wind force than those in the center and those at the shielded, "downwind" edge even less wind forces. The data also suggests that an array exposed to a 210 (or 150) degrees wind will experience the greatest wind forces.

Through analysis of the data, and experimental data collected in Newburyport, MA, by Ascension Technology, the worst case pressure coefficients for an exposed edge of an array have been determined. All of the modules between the two edges are given a $\mathrm{Cp}$ of $0.7^{\star} \mathrm{Cp}$ of exposed module. And, the shielded module in the row is given a $\mathrm{Cp}$ of $0.4{ }^{*} \mathrm{Cp}$ of exposed module. These percentages are based on correlation between Akins' data and the data gathered in Newburyport.

${ }^{6}$ Akins, R.E. Evaluation of Existing Force and Pressure Coefficients for Roof-Mounted Solar Collectors. June 18, 1998. 


\section{Equation used and Calculations}

18. The basic equation used to determine the normal force of the wind on the panels, Fn, is shown in the following table, along with the definition of the variables:

\begin{tabular}{|ll|}
\hline Basic Equation: & Fn $=$ Kz $\times$ GCp $\times(W S \times I) 2 \times$ Apv \\
$F n$ & Force normal to module \\
$K \mathrm{z}$ & Velocity Pressure Coefficient \\
$G C p$ & Gust and Pressure coefficient \\
$W s$ & Wind speed \\
1 & Importance factor \\
Apv & Normal Area of Module \\
\hline
\end{tabular}

19. The normal force, Fn, is then resolved into the horizontal and vertical forces based on the panel tilt angle. $\mathrm{Mm}$ is the mass of the PV module.

20. The mass of ballast, $\mathrm{Mb}$, required to prevent sliding of the array is determined by taking the factor of safety equation for the prevention of sliding as follows:

$$
F S=\mu f(M m+M b-F v)
$$

Fh

And solving the equation for the mass of ballast required to prevent sliding at a given factor of safety, as follows:

$$
M b=\frac{F h F s}{\mu f}-M m+F v
$$

21. Similarly, the mass of ballast required to prevent overturning is determined by the following equation:

$$
\begin{aligned}
& F S=\frac{t l / 2 *(M b+M m)}{\left(t / / 2{ }^{*} F v\right)+\left(t h / 2{ }^{*} F h(\text { tray })\right)+\left(H^{*} F h\right)} \\
& M b=\left(\left(t / 2{ }^{*} F v\right)+\left(\text { th } / 2{ }^{*} F h(\text { tray })\right)+\left(H^{*} F h\right)\right){ }^{*} \mathrm{Cp}^{*}(2 / \mathrm{tl}){ }^{*} \mathrm{Fs}-\mathrm{Mm}
\end{aligned}
$$

\section{Outputs}

22. The average ballast per roof tray required to prevent sliding is calculated based on the equation for sliding given above, using a cumulative $\mathrm{Fh}$ for all of the modules in the array.

23. The ballast required to prevent the corner module from overturning is calculated based on an isolated corner module and the equation given above for overturning.

24. The roof loading is also given as an output.

25. A calculation of the optimal distribution of ballast on trays in the array is given in the sheet "Analysis." The distribution is calculated based on the following two cases:

- In Case 1 the calculation is based on ballasting all the trays to prevent overturning. 
- In Case 2 all trays on the east, west, and north perimeter are ballasted to prevent overturning the remaining ballast required to prevent sliding is distributed evenly among the remaining modules. The result is given in the form of the following table:

\begin{tabular}{|c|c|c|c|c|c|c|}
\hline \multirow[b]{2}{*}{ Row: } & \multirow[b]{2}{*}{ \# Modules } & \multicolumn{3}{|c|}{ Position of Trays } & \multirow[b]{2}{*}{ Total } & \multirow[b]{2}{*}{$\begin{array}{c}\text { Average } \\
\text { Ballast per } \\
\text { Tray } \\
\end{array}$} \\
\hline & & end of row & next to end & center & & \\
\hline \multirow[t]{3}{*}{ North: } & 6 & & & & & \\
\hline & \# trays: & 2 & 2 & 3 & 7 & \\
\hline & $\begin{array}{r}\text { Ibs. of Ballast / } \\
\text { tray: }\end{array}$ & 636 & 1,047 & 824 & 5,837 & 834 \\
\hline \multirow[t]{3}{*}{ South: } & 3 & & & & & \\
\hline & \# trays: & 2 & 2 & 0 & 4 & \\
\hline & $\begin{array}{r}\text { Ibs. of Ballast / } \\
\text { tray: }\end{array}$ & 553 & 907 & 0 & 2,919 & 730 \\
\hline \multirow[t]{3}{*}{ Center: } & 0 & & & & & \\
\hline & \# trays: & 0 & 0 & 0 & 0 & \\
\hline & $\begin{array}{r}\text { Ibs. of Ballast / } \\
\text { trav: }\end{array}$ & 0 & 0 & 0 & 0 & 0 \\
\hline Totals & & & & & 8,760 & 796 \\
\hline
\end{tabular}

The table indicates the number of modules in each row next to the row designation. The row headed by "\# trays" indicates the number of trays in each of the tray positions. The nomenclature for tray positions are described in the following figure.
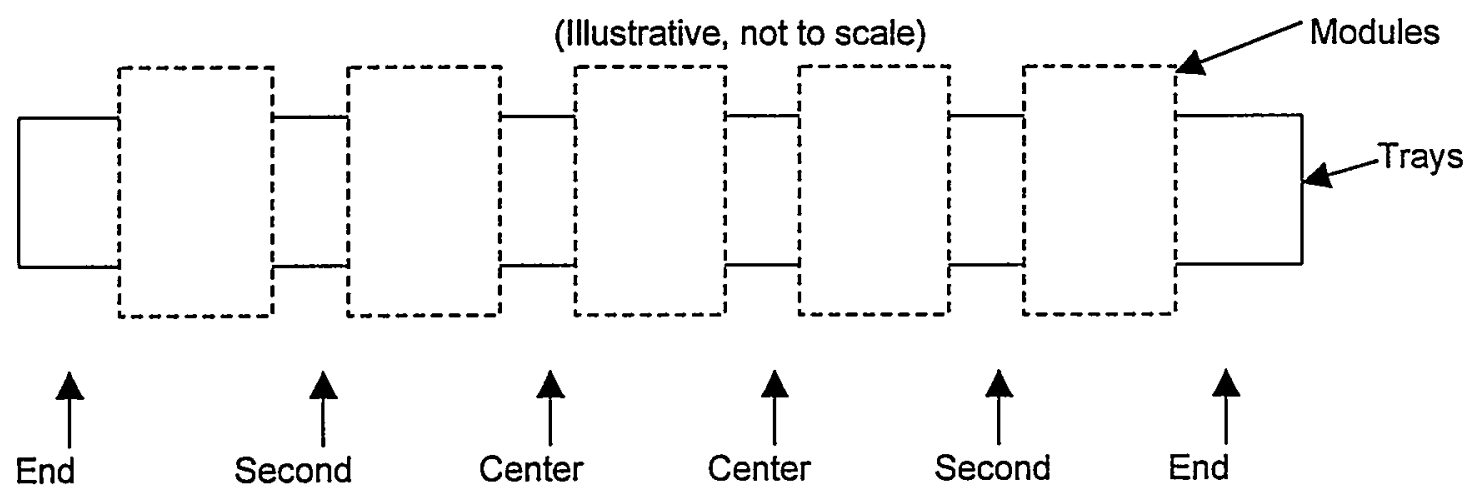